\title{
ATP8B2 wt Allele
}

National Cancer Institute

\section{Source}

National Cancer Institute. ATP8B2 wt Allele. NCI Thesaurus. Code C114664.

Human ATP8B2 wild-type allele is located in the vicinity of $1 \mathrm{q} 21.3$ and is approximately 26

$\mathrm{kb}$ in length. This allele, which encodes probable phospholipid-transporting AT Pase ID protein, plays a role in aminophospholipid translocation. 